\title{
Upper Gastrointestinal Bleeding From Aberrant Right Subclavian Artery-Esophageal Fistula
}

\author{
Shira Peress, MD, ${ }^{1}$ Wa'el Tuqan, MD, ${ }^{2}$ Austin Thomas, MD $^{2}$ \\ ${ }^{1}$ The University of Queensland Faculty of Medicine, Ochsner Clinical School, New Orleans, LA 2Department of Gastroenterology, Ochsner \\ Clinic Foundation, New Orleans, LA
}

Background: The most common aortic arch abnormality is an aberrant right subclavian artery (ARSA). ARSA-esophageal fistula is a rare sequela that can present with a life-threatening upper gastrointestinal (GI) bleed.

Case Report: We report the case of an 88-year-old male who presented with signs of upper Gl bleeding. Esophagogastroduodenoscopy demonstrated extrinsic compression of the upper third of the esophagus with ulceration. Imaging studies revealed ARSA posterior to the esophagus with pseudoaneurysm formation. These findings confirmed an upper GI bleed secondary to ARSA-esophageal fistula. The patient underwent prompt embolization of the ARSA pseudoaneurysm, followed a few days later by coil embolization of the ARSA pseudoaneurysm. Despite these interventions, the patient continued to have bleeding with anemia. He and his family opted to avoid any further interventions and instead pursued comfort care. The patient was discharged to hospice and died 3 months later.

Conclusion: ARSA-esophageal fistula is a rare but potentially lethal cause of upper Gl bleeding. Initial signs and symptoms can be subtle, but the presence of a Gl bleed requires immediate stabilization. Surgical interventions have been shown to have longerlasting success, but endovascular repair may be an option for patients who are deemed unfit for surgery but still require prompt stabilization. Regardless of the intervention, mortality rates for ARSA-esophageal fistula are high.

Keywords: Aberrant right subclavian artery, aneurysm, esophageal fistula, gastrointestinal hemorrhage

Address correspondence to Austin Thomas, MD, Department of Gastroenterology, Ochsner Clinic Foundation, 1514 Jefferson Hwy., New Orleans, LA 70121. Tel: (504) 842-4015. Email: authomas@ochsner.org

\section{INTRODUCTION}

Aberrant right subclavian artery (ARSA), or arteria lusoria, is the most common aortic arch abnormality, with a prevalence of $0.2 \%$ to $2.5 \% .^{1,2}$ ARSA is typically an incidental finding that seldom causes any symptoms. ${ }^{3}$ However, ARSA is prone to aneurysmal development that can remain asymptomatic or cause compressive symptoms, including shortness of breath and dysphagia lusoria secondary to extrinsic compression of the esophagus. ${ }^{3}$ The recurrent laryngeal nerve is also prone to a degree of constriction from ARSA, causing progressive hoarseness. An even rarer consequence is the development of ARSA-esophageal fistula that can present as a life-threatening upper gastrointestinal (Gl) bleed, so prompt diagnosis and management are essential for patient survival.

\section{CASE REPORT}

An 88-year-old male presented to the emergency department (ED) with a 1-day history of shortness of breath. He reported one episode of dark black, bloody stools 2 days prior. He also reported dysphagia for 6 months and hoarseness of voice for 1 week. He had an extensive cardiovascular history, including aortic stenosis status post transcatheter aortic valve replacement, thoracic aortic aneurysm (TAA), atrial fibrillation on warfarin, and congestive heart failure. A month and a half prior to his presentation, computed tomography (CT) angiography of the chest to evaluate the TAA demonstrated an ascending TAA and saccular pseudoaneurysm formation from an ARSA, resulting in marked mass effect and displacement of the esophagus (Figure 1). Bilateral carotid subclavian bypass was recommended; however, the patient declined surgery at the time.

On presentation to the ED, he was hemodynamically stable. Laboratory workup revealed hemoglobin of $6.5 \mathrm{~g} / \mathrm{dL}$ from a baseline of $11.0 \mathrm{~g} / \mathrm{dL}$. Prothrombin time was 17.1 seconds, with an international normalized ratio (INR) of 1.8. Following initial resuscitation with 2 units of packed red blood cells and intravenous pantoprazole, esophagogastroduodenoscopy (EGD) was performed and demonstrated extrinsic compression of the upper third of the esophagus, with associated areas of ulceration and visible underlying vasculature (Figure 2). EGD findings were concerning for development of ARSA-esophageal fistula and the potential for subsequent bleeding. Vascular surgery performed urgent embolization of the ARSA using Amplatzer plugs. 


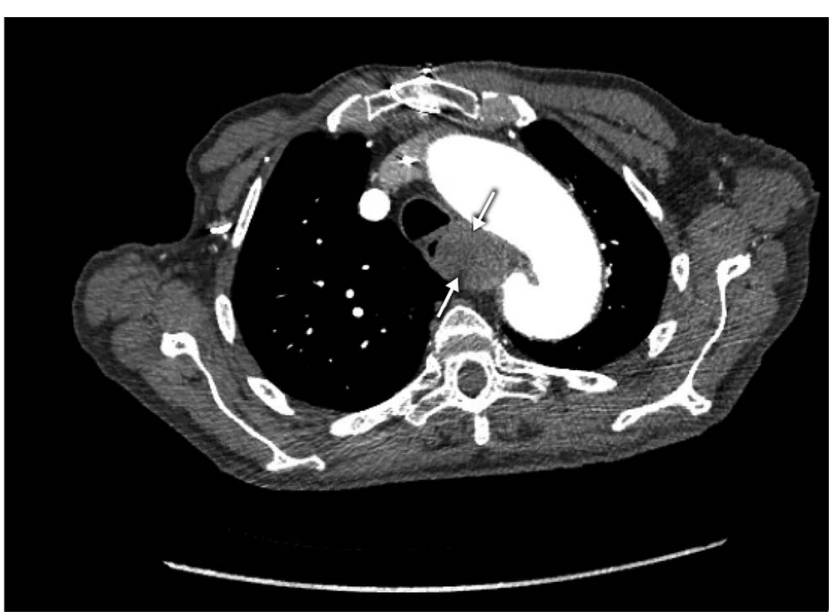

Figure 1. Computed tomography angiography of the chest demonstrates an ascending thoracic aortic aneurysm with saccular pseudoaneurysm formation. Arrows point to the aneurysm compressing the esophagus.
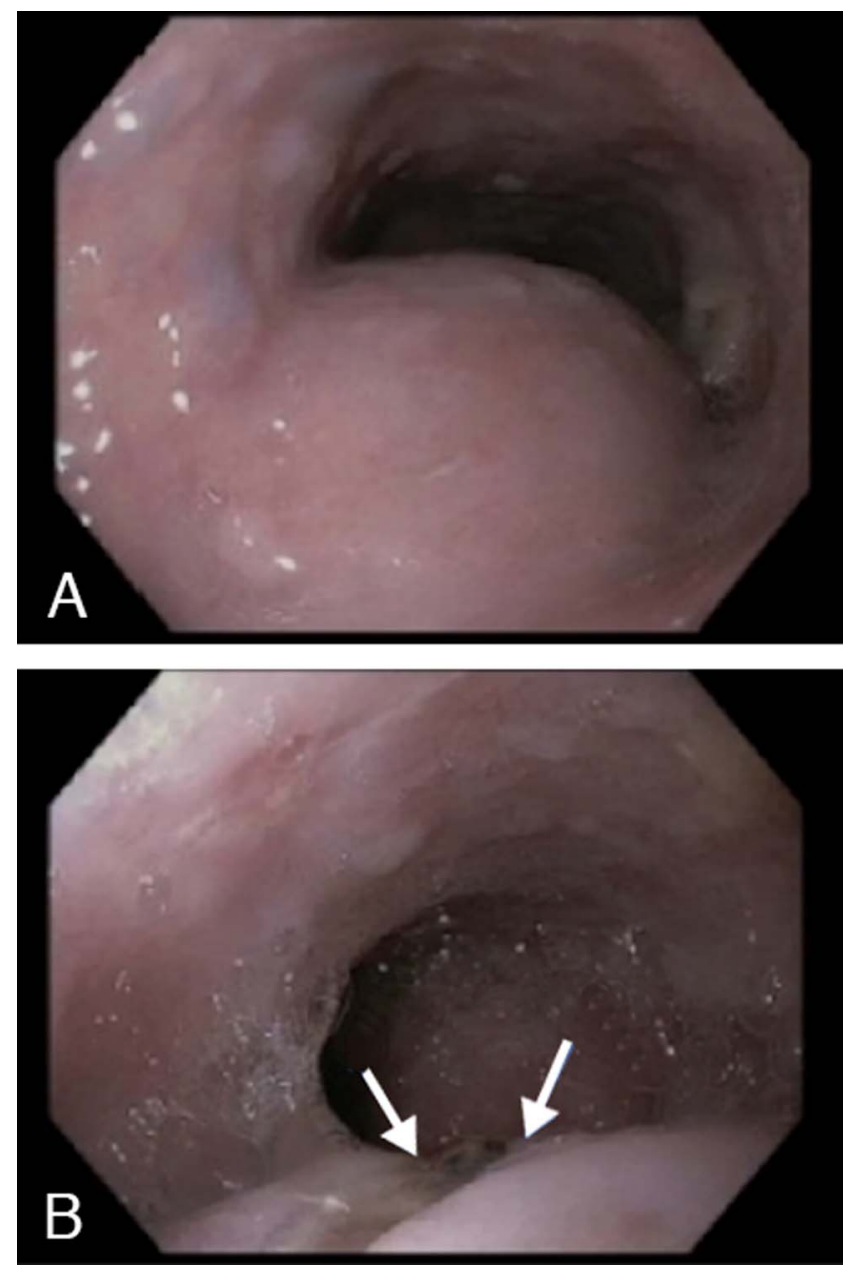

Figure 2. Esophagogastroduodenoscopy demonstrates (A) external compression into the lumen of the esophagus and (B) the inferior part of the compression with ulceration (arrows) and possible visible vessel.
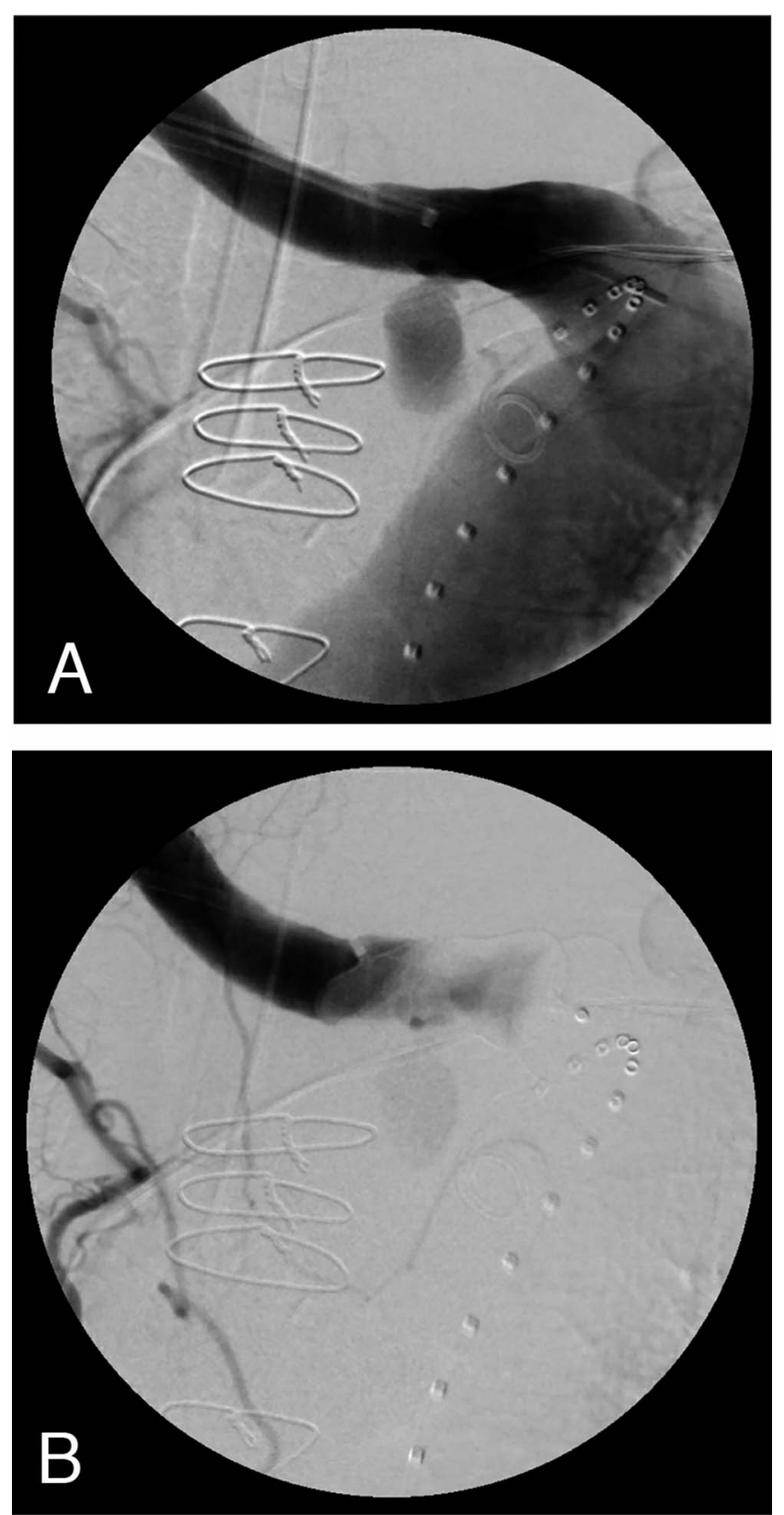

Figure 3. Interventional radiology imaging demonstrates (A) precoiled pseudoaneurysm and (B) postcoiled pseudoaneurysm.

The patient initially did well and had no further signs of bleeding. He was discharged 2 days after the procedure with hemoglobin of $7.7 \mathrm{~g} / \mathrm{dL}$ and INR of 1.2. One day after discharge, he presented again to the ED with worsening fatigue, weakness, and shortness of breath. He had 2 additional episodes of melena and a drop in hemoglobin to $6.5 \mathrm{~g} / \mathrm{dL}$. He was readmitted, and repeat CT angiography demonstrated a new bleed within the pseudoaneurysm sac. In conjunction with vascular surgery, interventional radiology performed a coil embolization of the ARSA pseudoaneurysm (Figure 3).

Despite these interventions, the patient continued to have ongoing signs of bleeding with anemia. He required multiple blood transfusions for stabilization, ultimately receiving 


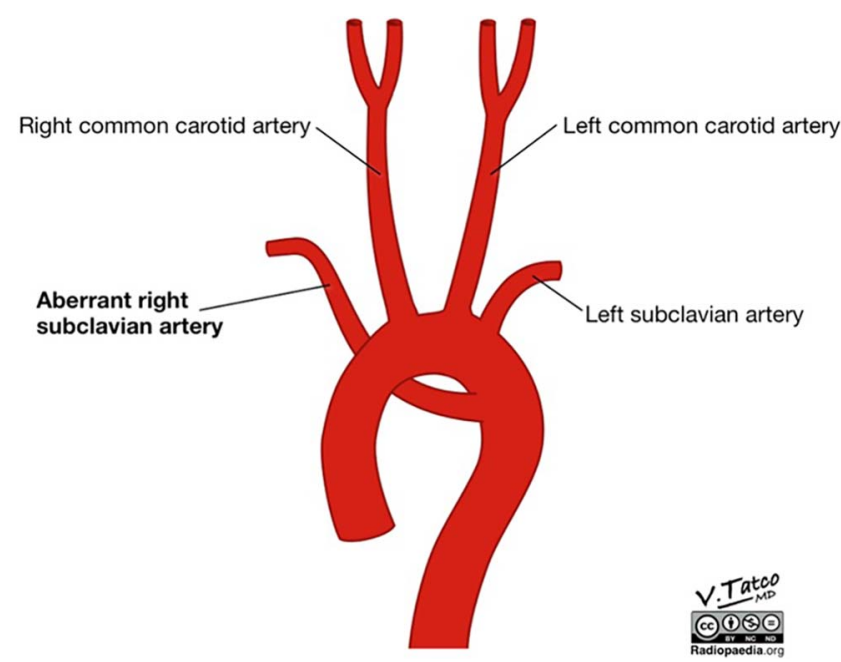

Figure 4. Schematic representation of aberrant right subclavian artery. (Image courtesy of Dr Vincent Tatco, Radiopaedia.org, rID: 52193 radiopaedia.org/cases/developmentof-aberrant-right-subclavian-artery-illustration)

5 units of packed red blood cells that helped improve his hemoglobin to $9.2 \mathrm{~g} / \mathrm{dL}$ and hematocrit to $28.5 \%$. After multidisciplinary team discussions, the patient and his family opted to avoid any further workup or surgical interventions and instead pursued comfort care. He was discharged to hospice 4 days after being readmitted and died 3 months later.

\section{DISCUSSION}

When ARSA is present, the right subclavian artery branches distal to the left subclavian artery and serves as the fourth branch of the left-sided aortic arch (Figure 4). From there, the artery travels posterior to the esophagus in $80 \%$ of cases but can also be found between the trachea and esophagus in $15 \%$ of cases and anterior to the trachea in $5 \%$ of cases. ${ }^{4}$ ARSA has been reported to have a female predominance as high as 3:1, although other studies suggest no significant sex discrepancy. ${ }^{5}$ ARSA can be associated with other medical conditions and is seen in up to $25 \%$ of patients with esophageal atresia and in $16 \%$ to $39 \%$ of patients with Down syndrome. .,7 $^{6}$

Despite its prevalence in the general population, ARSA is frequently asymptomatic and discovered incidentally on imaging. However, ARSA can present with dysphagia secondary to esophageal compression, a phenomenon known as dysphagia lusoria. ${ }^{8}$ Depending on the exact location, ARSA can cause some degree of compression of the recurrent laryngeal nerve, resulting in hoarseness, a condition known as Ortner syndrome. ${ }^{9}$ ARSA can also cause compression of the trachea, resulting in shortness of breath. With advancing age, ARSA is prone to aneurysmal development or sclerosis. ${ }^{3}$ The late presentation of dysphagia in our elderly patient is not uncommon, as dysphagia is more frequently seen in the elderly compared to younger patients with ARSA and can be attributed to decreased flexibility of the esophagus or increasing compression from the developing aneurysm. Some degree of atherosclerosis contributing to rigidity of the ARSA is also possible. ${ }^{10}$
In our review of literature, we found 35 reported cases of ARSA-esophageal fistula. ${ }^{1,11-43}$ Of the 35 cases, 33 cases are included in our summary table, while 2 cases were excluded due to inability to access the primary source or the source being in a language other than English (Table). ${ }^{13,20}$ Six cases were in the pediatric population, with patient ages ranging from 5 months to 11 years. ${ }^{22,28,30,34,37}$ Although diagnosis is typically made with CT imaging, endoscopic visualization may be the initial diagnostic test to exclude other causes, particularly in patients who are hemodynamically stable at the time of presentation. The most common etiology for development of ARSA-esophageal fistula appeared to be secondary to compression, friction, or pressure necrosis from recent instrumentation with an endotracheal tube, nasogastric tube, or tracheostomy tube, seen in 14 of the 33 summarized cases. ${ }^{14,15,17,19,21,22,24,27,29,31,38-41}$ Fistula development from prior placement of esophageal stent was noted in 5 cases. ${ }^{34,36,42,43}$ Other reported causes for fistula formation included placement of a salivary bypass tube and a possible consequence of gastric pull-up surgery. ${ }^{1,26}$

Fistula formation attributable to ARSA aneurysm with resultant GI bleeding is rare. Only 10 other cases attributed to this etiology have been reported. ${ }^{11,12,16,18,19,23,25,33,35,42}$ Only 1 patient with upper GI bleed secondary to ARSA aneurysm survived all bleeding episodes, and the patient required balloon tamponade with surgery to replace the aorta. ${ }^{33}$ Our patient survived the initial bleeding event, but died 3 months later, as he declined definitive surgical intervention to stop the recurrent bleeding.

Bleeding from ARSA-esophageal fistula is lifethreatening, with a high mortality rate at initial presentation, regardless of etiology. Of the 33 summarized cases, thirteen cases survived all episodes of bleeding (39\%). ${ }^{21,22,24,27,28,30,31,33,34,36-38,43}$ The severity of bleeding, in the setting of several comorbid conditions, likely contributed to the high mortality rate.

Opinions conflict regarding acute treatment for bleeding from ARSA-esophageal fistula secondary to aneurysm, with the historic approach being excision with reconstruction of the aorta and esophagus. ${ }^{33}$ A more recent approach (2000) is placement of an endovascular stent, but success with this approach is questionable because of the rates of infection that may result in the need for further surgery. ${ }^{44}$ Reported cases in adults involved treatment with surgery alone in 5 cases, ${ }^{11,16,26,30,38}$ endovascular repair alone in 2 cases, ${ }^{41,42}$ and a combination of endovascular and surgical intervention in 6 cases. ${ }^{28,29,31,35,36,43}$ Balloon tamponade was performed in 16 cases, $1,14,15,21,22,24,25,27-29,31-33,35-37$ with 3 of those 16 performed solely with endovascular repair. ${ }^{1,27,32}$ Six of the 11 patients who underwent either surgery alone or surgery with endovascular repair survived $(55 \%), 28,30,31,36,38,43$ whereas only 1 of the 5 cases of endovascular repair with or without balloon tamponade survived (20\%). ${ }^{27}$ Although the higher percentage of survival among patients who had surgery with or without endovascular repair compared to the 5 patients who underwent endovascular repair without surgery might suggest a better outcome with surgery, this discrepancy is likely confounded by patient factors and comorbidities for which surgical intervention is usually deferred, as well as the relatively low number of patient cases reported to have been treated with endovascular repair without surgery. 


\begin{tabular}{|c|c|c|c|c|c|}
\hline Study & Age, Sex & Medical History & Etiology & Treatment & Outcome \\
\hline Lynn, $1969^{11}$ & $57, M$ & Atherosclerosis, hypertension, angina & ARSA aneurysm & Surgery & Fatal \\
\hline Reynes et al, $1976^{12}$ & $72, F$ & Mediastinal mass & ARSA aneurysm & None & Fatal \\
\hline Livesay et al, $1982^{14}$ & $25, M$ & $\begin{array}{l}\text { Motor vehicle accident with traumatic } \\
\text { head injury }\end{array}$ & $\begin{array}{l}\text { Endotracheal tube, nasogastric tube, } \\
\text { and tracheostomy }\end{array}$ & Balloon tamponade, surgery & Fatal \\
\hline Belkin et al, $1984^{15}$ & $27, M$ & Head and neck squamous cell carcinoma & Nasogastric tube & Balloon tamponade, surgery & Fatal \\
\hline Edwards et al, $1984^{16}$ & $81, M$ & $\begin{array}{l}\text { Mass in right upper hemithorax (tortuous } \\
\text { innominate artery) }\end{array}$ & ARSA aneurysm & Surgery & Fatal \\
\hline Gossot et al, $1985^{17}$ & $72, F$ & $\begin{array}{l}\text { Type I aortic dissection with endoluminal } \\
\text { prosthesis, giant cell arteritis }\end{array}$ & $\begin{array}{l}\text { Endotracheal tube, nasogastric tube, } \\
\text { and tracheostomy }\end{array}$ & None & Fatal \\
\hline Kullnig, $1989^{18}$ & $66, M$ & Hypertension & ARSA aneurysm & None & Fatal \\
\hline Stone et al, $1990^{19}$ & $72, M$ & $\begin{array}{l}\text { Smoker, status post cardiopulmonary } \\
\text { bypass surgery }\end{array}$ & ARSA aneurysm, tracheostomy & None & Fatal \\
\hline Hirakata et al, $1991^{21}$ & $55, M$ & $\begin{array}{l}\text { Status post subtotal esophagectomy for } \\
\text { esophageal cancer }\end{array}$ & $\begin{array}{l}\text { Nasogastric tube, radiation arteritis, } \\
\text { and other surgical trauma }\end{array}$ & Balloon tamponade & Survived \\
\hline Miller et al, $1996^{22}$ & $11, F$ & $\begin{array}{l}\text { Status post craniotomy for intracerebral } \\
\text { hemorrhage }\end{array}$ & Endotracheal tube, nasogastric tube & Balloon tamponade, surgery & Survived \\
\hline Singha et al, $1998^{23}$ & $82, \mathrm{M}$ & $N / R$ & ARSA aneurysm & None & Fatal \\
\hline Feugier et al, $2002^{24}$ & $24, M$ & Polytrauma, burns, alcohol abuse & Nasogastric tube and tracheotomy & Balloon tamponade, surgery & Survived \\
\hline Lehmann et al, $2006^{25}$ & $78, M$ & $N / R$ & ARSA aneurysm & Balloon tamponade & Fatal \\
\hline Millar et al, $2007^{26}$ & $57, M$ & $\begin{array}{l}\text { Status post esophagectomy with gastric } \\
\text { pull-up for esophageal cancer }\end{array}$ & $\begin{array}{l}\text { Pressure from gastric pull-up vs } \\
\text { foreign body }\end{array}$ & Surgery & $\begin{array}{l}\text { Fatal (survived initial } \\
\text { hemorrhage but died } \\
18 \text { days later from } \\
\text { additional bleed) }\end{array}$ \\
\hline Inman et al, $2008^{1}$ & $63, M$ & Supraglottic squamous cell carcinoma & Salivary bypass tube & $\begin{array}{l}\text { Endovascular repair, balloon } \\
\text { tamponade }\end{array}$ & Fatal \\
\hline Magagna et al, $2008^{27}$ & $73, F$ & $\begin{array}{l}\text { Status post laryngectomy and } \\
\text { tracheostomy for laryngeal carcinoma }\end{array}$ & Tracheostomy & $\begin{array}{l}\text { Endovascular repair, balloon } \\
\text { tamponade }\end{array}$ & Survived \\
\hline Fuentes et al, $2010^{28}$ & $3, F$ & Esophageal atresia type III & Esophageal prosthesis & $\begin{array}{l}\text { Endovascular repair, balloon } \\
\text { tamponade, surgery }\end{array}$ & Survived \\
\hline Chapman et al, $2010^{29}$ & $34, F$ & Motor vehicle accident with trauma & $\begin{array}{l}\text { Endotracheal tube, nasogastric tube, } \\
\text { and tracheostomy }\end{array}$ & $\begin{array}{l}\text { Endovascular repair, balloon } \\
\text { tamponade, surgery }\end{array}$ & Fatal \\
\hline Situma et al, $2011^{30}$ & 5 months, $\mathrm{F}$ & Esophageal atresia with distal fistula & $\begin{array}{l}\text { Status post colonic esophageal } \\
\text { grafting }\end{array}$ & Surgery & Survived \\
\hline Jain et al, $2012^{31}$ & $57, F$ & $\begin{array}{l}\text { Status post cardiopulmonary bypass } \\
\text { surgery for scimitar syndrome }\end{array}$ & $\begin{array}{l}\text { Endotracheal tube, nasogastric tube, } \\
\text { and tracheostomy }\end{array}$ & $\begin{array}{l}\text { Endovascular repair, balloon } \\
\text { tamponade, surgery }\end{array}$ & Survived \\
\hline
\end{tabular}


Table. Continued

\begin{tabular}{|c|c|c|c|c|c|}
\hline Study & Age, Sex & Medical History & Etiology & Treatment & Outcome \\
\hline Pop et al, $2012^{32}$ & $67, M$ & $\begin{array}{l}\text { Status post transhiatal esophagectomy } \\
\text { for esophageal cancer, status post } \\
\text { pneumonectomy for lung cancer, } \\
\text { neuroendocrine liver cancer }\end{array}$ & $\begin{array}{l}\text { Damage to arterial wall from cervical } \\
\text { sepsis and/or staples from gastric } \\
\text { tubing }\end{array}$ & $\begin{array}{l}\text { Endovascular repair, balloon } \\
\text { tamponade }\end{array}$ & Fatal \\
\hline Takahashi et al, $2013^{33}$ & $63, M$ & $N / R$ & Infected ARSA aneurysm & Balloon tamponade, surgery & Survived \\
\hline \multirow[t]{2}{*}{ Lo et al, $2013^{34}$} & $\begin{array}{l}16 \text { months, } \\
\mathrm{N} / \mathrm{R}\end{array}$ & Esophageal atresia with distal fistula & Esophageal and Polyflex airway stent & $\begin{array}{l}\text { Endovascular repair, } \\
\text { Bougienage tamponade }\end{array}$ & Fatal \\
\hline & $\begin{array}{l}18 \text { months, } \\
\text { N/R }\end{array}$ & Esophageal atresia, duodenal atresia & Esophageal stent & Surgery, hydrostatic dilator & Survived \\
\hline Morisaki et al, $2014^{35}$ & $74, F$ & Rheumatic arthritis & ARSA aneurysm & $\begin{array}{l}\text { Endovascular repair, balloon } \\
\text { tamponade, surgery }\end{array}$ & Fatal \\
\hline Hosn et al, $2014^{36}$ & $29, \mathrm{~F}$ & Sleeve gastrectomy & Esophageal stent & $\begin{array}{l}\text { Endovascular repair, balloon } \\
\text { tamponade, surgery }\end{array}$ & Survived \\
\hline $\begin{array}{l}\text { Joynt and Grifka, } \\
2015^{37}\end{array}$ & 17 months, $\mathrm{F}$ & $N / R$ & Spontaneous development of fistula & Balloon tamponade, surgery & Survived \\
\hline Watanabe et al, $2015^{39}$ & $55, M$ & Intracranial hemorrhage & Nasogastric tube and tracheostomy & None & Fatal \\
\hline Oliveira et al, $2016^{38}$ & $20, M$ & Motor vehicle accident with polytrauma & $\begin{array}{l}\text { Endotracheal tube and nasogastric } \\
\text { tube }\end{array}$ & Surgery & Survived \\
\hline Kudose et al, $2017^{40}$ & $20, \mathrm{~F}$ & $\begin{array}{l}\text { VATER (vertebral, anal, tracheal, } \\
\text { esophageal, and renal) association, } \\
\text { primary pulmonary hypertension, } \\
\text { diabetes mellitus, atrial septal defect, } \\
\text { status post } 3 \text { lung transplants }\end{array}$ & Tracheostomy & None & Fatal \\
\hline $\begin{array}{l}\text { Shires and Rohrer, } \\
2018^{41}\end{array}$ & $44, \mathrm{~F}$ & $\begin{array}{l}\text { Gastroesophageal reflux disease, } \\
\text { hypertension, pneumonia }\end{array}$ & $\begin{array}{l}\text { Nasogastric tube, endotracheal tube, } \\
\text { and tracheostomy }\end{array}$ & Endovascular repair & Fatal \\
\hline Zheng et al, $2019^{42}$ & $67, M$ & $\begin{array}{l}\text { Esophageal and laryngeal cancer, } \\
\text { hypertension }\end{array}$ & $\begin{array}{l}\text { Esophageal stent and } \\
\text { pseudoaneurysm }\end{array}$ & Endovascular repair & Fatal \\
\hline Merlo et al, $2020^{43}$ & $29, \mathrm{~F}$ & $\begin{array}{l}\text { Tracheoesophageal fistula, } \\
\text { ventriculoperitoneal shunt for } \\
\text { hydrocephalus }\end{array}$ & Esophageal stent & Endovascular repair, surgery & Survived \\
\hline Present case, 2021 & $88, M$ & $\begin{array}{l}\text { Hypertension, transcatheter aortic valve } \\
\text { replacement, thoracic aortic aneurysm }\end{array}$ & ARSA aneurysm & Endovascular repair & $\begin{array}{l}\text { Fatal (survived initial } \\
\text { event, but died } 3 \\
\text { months after discharge } \\
\text { from recurrent bleeds) }\end{array}$ \\
\hline
\end{tabular}




\section{CONCLUSION}

ARSA-esophageal fistula is an uncommon and potentially fatal cause of Gl bleeding. Patients with known ARSA aneurysm should elicit a high index of suspicion, particularly those who present with concomitant worsening dysphagia. Given the high mortality with active bleeding, endovascular repair is a potential alternative for patients who are not suitable for surgery because of their comorbidities or high surgical risk. However, even with intervention, mortality remains high.

\section{ACKNOWLEDGMENTS}

The authors have no financial or proprietary interest in the subject matter of this article.

\section{REFERENCES}

1. Inman JC, Kim P, McHugh R. Retroesophageal subclavian artery-esophageal fistula: a rare complication of a salivary bypass tube. Head Neck. 2008;30(8):1120-1123. doi: 10.1002/hed.20854

2. Nakatani T, Tanaka S, Mizukami S, Okamoto K, Shiraishi Y, Nakamura T. Retroesophageal right subclavian artery originating from the aortic arch distal and dorsal to the left subclavian artery. Ann Anat. 1996;178(3):269-271. doi: 10.1016/S0940-9602(96)80064-1

3. Abraham V, Mathew A, Cherian V, Chandran S, Mathew G. Aberrant subclavian artery: anatomical curiosity or clinical entity. Int J Surg. 2009;7(2):106-109. doi: 10.1016/j.ijsu.2009.01.009

4. Gomes MM, Bernatz PE, Forth RJ. Arteriosclerotic aneurysm of an aberrant right subclavian artery. Dis Chest. 1968;54(6):549-552. doi: 10.1378/chest.54.6.549

5. Molz G, Burri B. Aberrant subclavian artery (arteria lusoria): sex differences in the prevalence of various forms of the malformation. Evaluation of 1378 observations. Virchows Arch A Pathol Anat Histol. 1978;380(4):303-315. doi: 10.1007/BF00431315

6. Berthet S, Tenisch E, Miron MC, et al. Vascular anomalies associated with esophageal atresia and tracheoesophageal fistula. J Pediatr. 2015;166(5):1140-1144.e2. doi: 10.1016/j.jpeds.2015.01.038

7. Chaoui R, Heling KS, Sarioglu N, Schwabe M, Dankof A, Bollmann R. Aberrant right subclavian artery as a new cardiac sign in second- and third-trimester fetuses with Down syndrome. Am J Obstet Gynecol. 2005;192(1):257-263. doi: 10.1016/j.ajog.2004.06.080

8. Levitt B, Richter JE. Dysphagia lusoria: a comprehensive review. Dis Esophagus. 2007;20(6):455-460. doi: 10.1111/j.1442-2050.2007.00787.x

9. Bickle IC, Kelly BE, Brooker DS. Ortner's syndrome: a radiological diagnosis. Ulster Med J. 2002;71(1):55-56.

10. Kantarceken B, Bulbuloglu E, Yuksel M, Cetinkaya A. Dysphagia lusorium in elderly: a case report. World J Gastroenterol. 2004;10(16):2459-2460. doi: 10.3748/wjg.v10.i16.2459

11. Lynn RB. Kommerell's diverticulum with esophago-arterial fistula. Can J Surg. 1969;12(3):331-333.

12. Reynes JB, Errasti CA, Ercoreca FJB, Oñate Landa A. Letter: aneurysm of aberrant right subclavian artery with esophageal perforation. Chest. 1976;70(1):105. doi: 10.1378/chest.70.1.105a

13. Merchant FJ, Nichols RL, Bombeck CT. Unusual complication of nasogastric esophageal intubation-erosion into an aberrant right subclavian artery. J Cardiovasc Surg (Torino). 1977;18(2):147-150.
14. Livesay JJ, Michals AA, Dainko EC. Anomalous right subclavian arterial esophageal fistula: an unusual complication of tracheostomy. Tex Heart Inst J. 1982;9(1):105-108.

15. Belkin RI, Keller FS, Everts EC, Rösch J. Aberrant right subclavian artery-esophageal fistula: a cause of overwhelming upper gastrointestinal hemorrhage. Cardiovasc Intervent Radiol. 1984;7(2):87-89. doi: 10.1007/BF02552686

16. Edwards BS, Edwards WD, Connolly DC, Edwards JE. Arterial-esophageal fistulae developing in patients with anomalies of the aortic arch system. Chest. 1984;86(5):732-735. doi: $10.1378 /$ chest.86.5.732

17. Gossot D, Nussaume O, Kitzis M, Cohen G, Chalaux G, Andreassian $B$. Fatal hematemesis due to erosion of a retro-esophageal right subclavian artery by an esophagogastric tube. Article in French. Presse Med. 1985;14(31):1655-1656.

18. Kullnig P. Aneurysm of an aberrant right subclavian artery with bleeding into the esophageal wall. Semin Roentgenol. 1989;24(2):75-76. doi: 10.1016/0037-198x(89)90027-8

19. Stone WM, Brewster DC, Moncure AC, Franklin DP, Cambria RP, Abbott WM. Aberrant right subclavian artery: varied presentations and management options. J Vasc Surg. 1990;11(6):812-817.

20. Ikeda T, Yokota Y, Ando F, et al. A case of an aberrant subclavian artery-esophageal fistula due to prolonged nasogastric intubation. Article in Japanese. Kyobu Geka. 1991;44(12):1045-1047.

21. Hirakata R, Hasuo K, Yasumori K, Yoshida K, Masuda K. Arterioenteric fistulae: diagnosis and treatment by angiography. Clin Radiol. 1991;43(5):328-330. doi: 10.1016/s0009-9260(05)80541-0

22. Miller RG, Robie DK, Davis SL, et al. Survival after aberrant right subclavian artery-esophageal fistula: case report and literature review. J Vasc Surg. 1996;24(2):271-275. doi: 10.1016/s0741-5214(96)70103-9

23. Singha NK, Hale SJ, Kuhlman JE. Arterio-esophageal communication from a ruptured aberrant right subclavian artery aneurysm. CT diagnosis. Clin Imaging. 1998;22(2):117-121. doi: 10.1016/s0899-7071(97)00072-7

24. Feugier $P$, Lemoine $L$, Beaudoin N, Chevalier JM. Aberrant right subclavian arterioesophageal fistula: endovascular occlusion via a transbrachial approach. Eur J Vasc Endovasc Surg. 2002;23(1):77-78. doi: 10.1053/ejvs.2001.1512

25. Lehmann B, Clemetson I, Fantin AC, et al. Arterioesophageal fistula secondary to rupture of an aberrant right subclavian artery aneurysm: a rare differential diagnosis in upper gastrointestinal bleeding. Endoscopy. 2006;38(7):762. doi: 10.1055/s-2006-925172

26. Millar A, Rostom A, Rasuli P, Saloojee N. Upper gastrointestinal bleeding secondary to an aberrant right subclavian artery-esophageal fistula: a case report and review of the literature. Can J Gastroenterol. 2007;21(6):389-392. doi: $10.1155 / 2007 / 398213$

27. Magagna P, Abbiate N, Mansi G, et al. Endovascular treatment of aberrant right subclavian (lusorian) artery to oesophagus fistula: a case report. Vasc Endovascular Surg. 2008;42(4):394-396. doi: 10.1177/1538574408315993

28. Fuentes S, Cano I, López M, et al. Arterial-esophageal fistula: a severe complication in children with cardiovascular abnormalities. Pediatr Surg Int. 2010;26(3):335-337. doi: 10.1007/s00383-009-2532-6

29. Chapman JR, Sedghi S, Christie BD, Nakayama DK, Wynne JL. Aberrant right subclavian artery-esophageal fistula. Am Surg. 2010;76(12):1430-1432. 
30. Situma M, Kubiak R, Numanoglu A, Wood R, Brooks A, Millar AJ. Near-fatal bleeding from an aberrant subclavian artery following colonic interposition for oesophageal atresia. Pediatr Surg Int. 2011;27(10):1131-1133. doi: 10.1007/s00383-011-2881-9

31. Jain KK, Braze AJ, Shapiro MA, Perez-Tamayo RA. Aberrant right subclavian artery-esophageal fistula and severe gastrointestinal bleeding after surgical correction of scimitar syndrome. Tex Heart Inst J. 2012;39(4):571-574.

32. Pop D, Venissac N, Nadeemy AS, Schneck AS, Aze O, Mouroux J. Lesson to be learned: beware of lusoria artery during transhiatal esophagectomy. Ann Thorac Surg. 2012;94(3):1010-1011. doi: 10.1016/j.athoracsur.2012.01.092

33. Takahashi S, Okada K, Orihashi K, Sueda T. Arterio-oesophageal fistula caused by aberrant right subclavian artery aneurysm. Interact Cardiovasc Thorac Surg. 2013;16(6):920-922. doi: 10.1093/icvts/ivt083

34. Lo A, Baird R, De Angelis P, et al. Arterioesophageal fistula after stenting for esophageal atresia. J Pediatr Gastroenterol Nutr. 2013;56(5):e30-e31. doi: 10.1097/MPG.0b013e31824ffd7f

35. Morisaki A, Hirai H, Sasaki Y, Hige K, Bito Y, Suehiro S. Aortoesophageal fistula after endovascular repair for aberrant right subclavian artery aneurysm. Ann Thorac Cardiovasc Surg. 2014;20 Suppl:790-793. doi: 10.5761/atcs.cr.12.02153

36. Hosn MA, Haddad F, El-Merhi F, Safadi B, Hallal A. Repair of an aberrant subclavian arterioesophageal fistula following esophageal stent placement. World J Gastrointest Surg. 2014;6(6):117-121. doi: 10.4240/wjgs.v6.i6.117

37. Joynt MR, Grifka RG. Spontaneous aberrant right subclavian arterio-oesophageal fistula in a previously healthy child. Cardiol Young. 2015;25(7):1425-1427. doi: $10.1017 / S 1047951114002388$
38. Oliveira E, Anastácio M, Marques A. Aberrant right subclavian artery-esophageal fistula: massive upper gastrointestinal hemorrhage secondary to prolonged intubation. Braz J Anesthesiol. 2016;66(3):318-320. doi: 10.1016/j.bjane.2013.07.019

39. Watanabe M, Suzuki K, Fujinaga K, et al. Postmortem diagnosis of massive gastrointestinal bleeding in a patient with aberrant right subclavian artery-esophageal fistula. Acute Med Surg. 2015;3(2):139-142. doi: 10.1002/ams2.136

40. Kudose S, Pineda J, Saito JM, Dehner LP. Aberrant right subclavian artery-esophageal fistula in 20-year-old with VATER association. J Pediatr Intensive Care. 2017;6(2):127-131. doi: $10.1055 / \mathrm{s}-0036-1584812$

41. Shires CB, Rohrer MJ. Anomalous right subclavian artery-esophageal fistulae. Case Rep Vasc Med. 2018;2018:7541904. doi: 10.1155/2018/7541904

42. Zheng $S$, Wang $X$, Chen $S$, et al. A pseudoaneurysm of aberrant right subclavian artery caused by esophageal stent placement because of esophageal stricture after endoscopic submucosal dissection. Surg Laparosc Endosc Percutan Tech. 2019;29(5):e69-e71. doi: 10.1097/SLE.0000000000000696

43. Merlo A, Farber M, Ohana E, Pascarella L, Crowner J, Long J. Aberrant right subclavian artery to esophageal fistula: a rare case and its management. Ann Thorac Surg.2020;110(2):e85-e86. doi: 10.1016/j.athoracsur.2019.12.045

44. Jonker FHW, Schlosser FJV, Geirsson A, Sumpio BE, Moll FL, Muhs BE. Endograft collapse after thoracic endovascular aortic repair. J Endovasc Ther. 2010;17(6):725-734. doi: $10.1583 / 10-3130.1$

This article meets the Accreditation Council for Graduate Medical Education and the American Board of Medical Specialties Maintenance of Certification competencies for Patient Care and Medical Knowledge.

(C2021 by the author(s); licensee Ochsner Journal, Ochsner Clinic Foundation, New Orleans, LA. This article is an open (c) (i) access article distributed under the terms and conditions of the Creative Commons Attribution (CC BY) license (creativecommons.org/licenses/by/4.0/legalcode) that permits unrestricted use, distribution, and reproduction in any medium, provided the original author(s) and source are credited. 